\title{
LABOUR PRODUCTIVITY AND ECONOMIC GROWTH IN THE EU IN POST-CRISIS PERIOD
}

\author{
Astra Auzina-Emsina \\ Riga Technical University, Latvia \\ cross'ref http://dx.doi.org/10.5755/j01.em.19.3.7819
}

\begin{abstract}
Labour productivity and economic growth are the major factors to sustain and improve the performance and competitiveness of countries. The paper is devoted to the analysis of recent trends of labour productivity and economic growth in the European Union (EU) countries in post-crisis period in comparison with the trends in pre-crisis and crisis periods. The paper analyses the impact of changes in labour productivity and the effect on the macroeconomic indicators. The research focuses on the European Union countries that experienced the most severe crisis and afterwards the most rapid recovery in post-crisis period (as Latvia, Lithuania, and Estonia). The research findings argue that there are weak or no relations between productivity increase and economic growth in pre-crisis period and the first phase of post-crisis period; however, the increase of productivity during the crisis is a significant driver of the economy after a period of time. The research covers the time period from 2004 to 2012 that can be subdivided into three periods - 2004-2007 (precrisis), 2008-2010 (crisis) and starting from 2011 (post-crisis). It should be stressed that "precrisis" period is defined only for research purposes (to compare pre and post-crises periods) and it is not an official definition of this time period, as well economic cycles strongly vary amid the countries.
\end{abstract}

The type of the article: Research report.

Keywords: labour productivity, economic growth, global competitiveness, crisis, post-crisis. JEL Classification: J24, O40, O47.

\section{Introduction}

Labour productivity and economic growth are strategic factors in any economy nowadays. It is related to the fact that labour productivity depends on the availability and quality of labour resources and applied technologies. Hence, labour productivity is highly correlated with entrepreneurship and economic activity in the economy, specialisation, unemployment, competitive advantage etc. As a result, labour productivity heavily influences the production process and production costs. And production costs affect the competitiveness of nations in the global market.

It must be admitted that the issues and problems related to the labour productivity in various eras of economic cycle (for example, in the post-crisis period) are relatively uncovered topic in economic literature. Most of the studies devoted to post-crisis effects are devoted to the Asian economic crisis (as Rhee \& Pyo (2010) on Korea's crisis) or the Russian crisis (as Ahrend (2006)). It is most noticeable when specific countries are being investigated regarding the more recent economic crisis.

The review of recent literature on the research devoted to the productivity in Latvia, Lithuania, and Estonia shows that many studies investigating the relation between innovations and productivity (e.g. Masso \& Vahter (2012) examined the service sector in Estonia and the authors found that the association between technological innovation and productivity is stronger in the less knowledge-intensive service sector), foreign direct investment and productivity (e.g. Degutis \& Tvaronavičiene (2006), and Snieska \& Simkunaite (2009)), and labour productivity in a certain sector (e.g. the paper of Saboniene \& Karazijiene (2012) on Lithuanian manufacturing sector). At present, only a few studies are devoted to competitiveness in the post-crisis period in Latvia, 
Lithuania, and Estonia, and the majority address the issues related to financial market and currency exchange rates (e.g. Darvas (2011)).

In the past decade or even before, the issues related to the competitiveness of a certain industry, region and nation were examined in numerous studies. Global Competitiveness Index (GCI), elaborated by World Economic Forum (WEF), is widely applied to evaluate and rank countries depending on the level of global competitiveness. GCI represents the competitiveness of every country included on the report through the framework of business environment (including such factors as basic requirements (institutions, infrastructure etc.), efficiency, and innovation). Despite the focus on the business conditions, GCI is widely used in international comparisons and rankings regarding the global competitiveness.

Some authors are critical about the overestimated importance of the concept of global and national competitiveness. Lall (2001) raised the question whether national competitiveness is a real problem or "dangerous obsession" and this question is still open.

In recent years, the studies and research devoted to the critical analysis of GCI, including optional improvements (as Xia, Liang, Zhang \& Wu (2012)), upgraded methodologies and replacement indicators (as Podobnik, Horvatic, Kenett \& Stanley (2012)) are more numerous than those studies that recognize GCI as a general indicator to estimate and compare nations regarding the global competitiveness. Xia et al. (2012) argue that WEF should refine GCI methodology including national culture as an additional factor so that GCI can become a much better predictor of economic growth, the authors admit that GCI can only be meaningful when it is better at predicting economic growth than other variables, otherwise other well established indices should be used to make predictions about national economies. Podobnik et al. (2012) examined how the level of competitiveness affects the dynamics of a country's wealth during a recession, and the authors developed a new measure, which is called a relative competitiveness, to evaluate an economy's competitiveness relative to its GDP.

At the same time some studies on national competitiveness exclude GCI, but macroeconomic indicators as real GDP growth rate, GDP per capita, unit labour costs, inflation etc. and relations between these indicators are examined in order to evaluate and estimate the national competitiveness. For example, Fagerberg \& Srholec (2007) examined several relations such as the relations between GDP per capita in PPPs and real GDP growth rate, unit labour costs and real GDP growth rate etc. in order to detect and analyse competitiveness in a certain time period.

On the basis of the literature review, this approach has been selected as the most appropriate and effective for the study instead of application of the index as it cannot be used in time-series correlation analysis. At the same time, the GCI data are used in general analysis to represent global trends.

The question whether there is a strong and stable relation between labour productivity and economic growth and, as a result, national competitiveness, is unclear. Hence, the goal of the research is to analyse the recent trends of labour productivity and economic growth in post-crisis period in comparison with the trends in pre-crisis and crisis periods, taking into account the impact of labour productivity increase on national competitiveness in the global market.

The research is focused to answer the research questions: do both labour productivity and economic growth rate increase in post-crisis and have these indicators a strong relationship between them.

For this purpose, the countries that are most appropriate for this study were selected, exact time periods or stages of economic cycles for the selected countries (pre-crisis, crisis, and postcrisis) were defined, the trends of labour productivity and economic growth in various stages of economic cycle, as well as the trends of national competitiveness were analyzed; also the impact factors were determined. The research results were concluded by elaborating recommendations.

The results of the analysis imply that the possible existence of strong and direct relation between productivity and economic growth is overestimated. The results show that the existence of the lagged (transition) effect should be taken into consideration when labour productivity and economic growth relations are analysed. 


\section{Method}

As quantitative and qualitative data analysis methods, as well as analytic method have been used in the research, several indicators have been selected and are used as an analytic tool in order to evaluate the dynamics and impact in the research period. The following indicators have been used in the study:

1) labour productivity per person employed (EU27=100);

2) labour productivity per hour worked $(E U 27=100)$;

3) labour productivity (\% change in comparison with the previous period);

4) real GDP (billion EUR; chain-linked, reference year 2005);

5) real GDP (index, 2007=100 and 2008=100);

6) real GDP growth rate (\% change in comparison with the previous period);

7) Global Competitiveness Index (rank of a country).

The research is focused to examine the effects in the post crisis period, however, the pre-crisis and crisis period are defined and used for comparison and identifying shifts and influences. The research covers the time period from 2004 to 2012 that can be subdivided into three periods - 20042008 (pre-crisis), 2008-2010 (crisis) and starting from 2011 (post-crisis). It should be stressed that the "pre-crisis" period is defined only for research purposes (to compare the pre- and post-crises periods) and it is not an official definition of this time period. The most characteristic features of every period are summarized in Table 1 .

Table 1. Research sub-periods and major features

\begin{tabular}{|l|l|l|l|}
\hline \multicolumn{1}{|c|}{ Period } & \multicolumn{1}{|c|}{ Pre-crisis } & \multicolumn{1}{c|}{ Crisis } & \multicolumn{1}{c|}{ Post-crisis } \\
\hline \multicolumn{1}{|c|}{ Time } & \multicolumn{1}{c|}{ 2004-2007 } & \multicolumn{1}{c|}{ 2008-2010 } & \multicolumn{1}{c|}{ Since 2011 } \\
\hline $\begin{array}{l}\text { General } \\
\text { characteristics }\end{array}$ & $\begin{array}{l}\text { High growth rates (even } \\
\text { booming in some sectors (as } \\
\text { construction and real estate); } \\
\text { wage increase, slow or no } \\
\text { productivity increase, inflation, } \\
\text { low unemployment, optimistic } \\
\text { expectations. }\end{array}$ & $\begin{array}{l}\text { Economic decline, } \\
\text { unemployment increase, } \\
\text { wage cut, austerity } \\
\text { measures, demand and } \\
\text { purchasing power decline. }\end{array}$ & $\begin{array}{l}\text { Stable (even high (above } \\
\text { annual growth rates, employment } \\
\text { increase, wage increase, demand } \\
\text { and purchasing power increase, } \\
\text { inflation, investments in } \\
\text { production capacities and } \\
\text { construction. }\end{array}$ \\
\hline
\end{tabular}

Source: the author's elaboration on the basis of the performed macroeconomic indicators' analysis.

In addition, only one indicator (labour productivity per person employed (EU28=100)) has been analysed for a longer time period (2000-2013) in order to identify the general trends outside the research period, due to the fact that the trends have a significant impact on the topic and period researched.

In the research, the main data source is the Eurostat data base. Eurostat base is used as a data source of productivity and economic growth indicators. As the Eurostat data base's indicators are published according to a unified methodology for all countries examined in the research, all data are comparable (with other countries included in the data base; and with previous periods). The data source for GCI is Global Competitiveness Reports from 2006 till 2013 elaborated by WEF (2013).

The research is focused on Latvia, Lithuania, and Estonia as these European Union countries experienced the fastest economic growth during the pre-crisis period, the most severe economic decline during the crisis period and the fastest economic recovery in the post-crisis period. In addition, the statistics on the average level of the EU countries are applied for drawing comparisons and making analysis. In the research, the EU is a union of 28 countries if not mentioned otherwise.

\section{Results}

The European Union, in general, and the majority of the EU member states are very cautious about the regional and national competitiveness in the global market. Any signal of economic slowdown is taken seriously and many steps are taken to recover and revive the economy. The dynamics of the EU's real GDP show that the largest economic activity and largest annual real GDP 
was in 2008 (so it is the peak point of the EU economy) (Figure 1). However, eleven (Denmark, Estonia, Ireland, Greece, France, Italy, Latvia, Luxembourg, Portugal, Sweden, the UK) out of twenty eight current EU countries already experienced the crisis in 2008 and the highest point or peak point was observed in 2007 (Table 2).

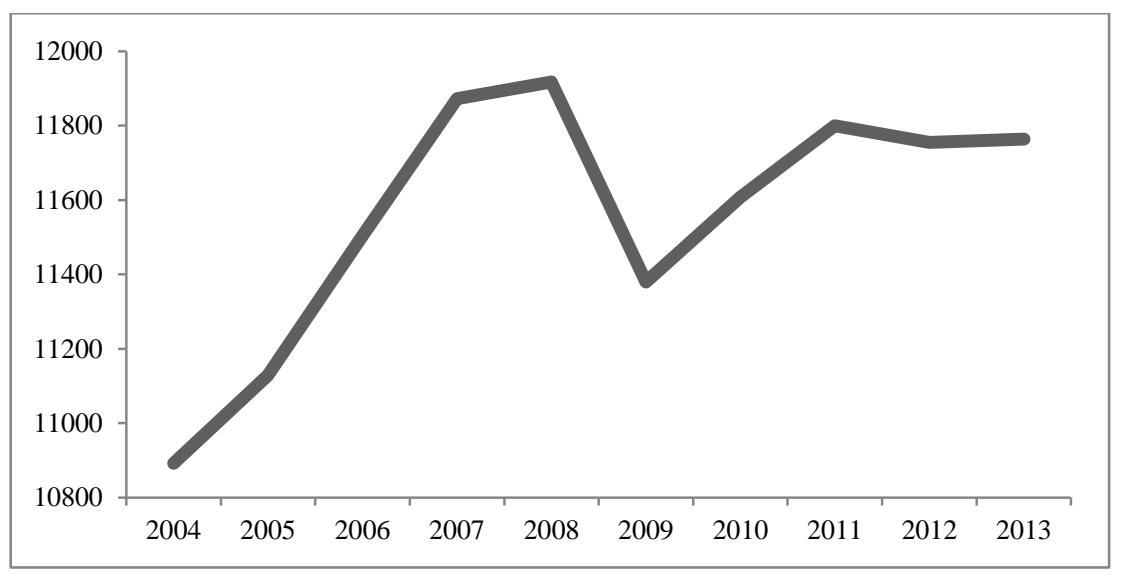

Figure 1. Dynamics of the EU's real GDP 2004-2013 (billion EUR; chain-linked, reference year 2005)

Due to the fact that in the group of countries, which as the first ones experienced the recession, were such countries as France, Italy and the UK (that are three of five largest EU economies), it led to the gradual slowdown of economic development in the common market. The above-stated eleven countries accounted for $54 \%$ of the total EU economy in 2007. Henceforward, the statistical data indicated that a half of the EU economy was in recession already in 2007. The years of 2007 and 2008 are the peak points or breaking points.

Economic growth is a complex process and it is determined by numerous domestic and global factors. In 2013, twenty EU countries had smaller real economies in comparison with the peak year (estimated by real GDP levels). Figure 1 shows that the total real size of the EU economy still lags behind (99\% of the volume of real economy in 2008). The positive trend is that for the majority of countries the crisis is over and a gradual or sharp recovery takes place.

The scope of the macroeconomic impact of the crisis on the economies varies amid the countries (Table 2). It is worth to stress that the majority of the EU countries have not gained back the share of the economy lost during the crisis. According to the Eurostat data only the following countries have larger economies in 2013 than in highest point in the pre-crisis (Table 2, grey highlights): Belgium, Germany, France, Luxembourg, Austria, Poland, Slovakia, and Sweden.

At the same time, Latvia, Lithuania and Estonia experienced the largest recessions within the EU and hence these countries are selected for a more detailed study. Latvia's economy fell by $21 \%$ in 2008-2010 (3-year crisis), Lithuania's economy - by 15\% in 2009 (one-year crisis), Estonia's economy - by $18 \%$ in 2008-2009 (2-year crisis). The data argue for neither those countries nor the EU economy in general had gained back the economic size and power of 2007. However, it should be stressed that some EU countries that are still in crisis as Greece and the new member state, Croatia, are not analyzed in this research.

Some EU countries (as Czech Republic, Spain, Italy, Cyprus, the Netherlands, Portugal, Slovenia, Finland) had experienced once again economic slowdown and relative minor economic decline (in most cases not larger than -2.5\%) in 2012 and 2013. Therefore, it is so important to detect what kind of activities helps to stop the crisis and avoid the further economic slowdowns in the post-crisis period. These findings and results are valuable for the policy makers, first of all, as well for the other economic agents (entrepreneurs, employees, NGOs etc.) in the economy. 
Table 2. The EU economies after the crisis

\begin{tabular}{|c|c|c|c|}
\hline Country & $\begin{array}{l}\text { Peak point } \\
\text { (Year) }\end{array}$ & $\begin{array}{c}2012 \\
(\% \text { of real GDP in the peak year ) }\end{array}$ & $\begin{array}{c}2013 \\
\text { (\% of real GDP in the peak year ) }\end{array}$ \\
\hline $\begin{array}{l}\text { European Union } \\
\text { ( } 28 \text { countries })\end{array}$ & 2008 & (x) & (2) \\
\hline $\begin{array}{l}\text { European Union } \\
(27 \text { countries })\end{array}$ & 2008 & 98.7 & 98.8 \\
\hline Euro area (17 countries) & 2008 & 98.3 & 97.9 \\
\hline Belgium & 2008 & 101.1 & 101.3 \\
\hline Bulgaria & 2008 & 97.2 & 98.0 \\
\hline Czech Republic & 2008 & 98.6 & 97.7 \\
\hline Denmark & 2007 & 95.6 & 95.9 \\
\hline Germany & 2008 & 102.7 & 103.1 \\
\hline Estonia & 2007 & 96.2 & 97.0 \\
\hline Ireland & 2007 & 92.7 & 92.4 \\
\hline Greece & 2007 & 79.4 & 76.3 \\
\hline Spain & 2008 & 94.4 & 93.3 \\
\hline France & 2007 & 100.5 & 100.7 \\
\hline Croatia & 2008 & 88.7 & 87.9 \\
\hline Italy & 2007 & 93.2 & 91.5 \\
\hline Cyprus & 2008 & 97.5 & 92.2 \\
\hline Latvia & 2007 & 87.5 & 91.1 \\
\hline Lithuania & 2008 & 95.1 & 98.3 \\
\hline Luxembourg & 2007 & 98.3 & 100.4 \\
\hline Hungary & 2008 & 94.1 & 95.1 \\
\hline Malta & 2008 & 103.6 & 106.4 \\
\hline Netherlands & 2008 & 97.5 & 96.7 \\
\hline Austria & 2008 & 101.5 & 101.9 \\
\hline Poland & 2008 & 112.5 & 114.3 \\
\hline Portugal & 2007 & 94.6 & 93.2 \\
\hline Romania & 2008 & 95.0 & 98.4 \\
\hline Slovenia & 2008 & 91.5 & 90.5 \\
\hline Slovakia & 2008 & 104.1 & 105.1 \\
\hline Finland & 2008 & 96.2 & 94.9 \\
\hline Sweden & 2007 & 104.5 & 106.2 \\
\hline United Kingdom & 2007 & 97.0 & 98.6 \\
\hline
\end{tabular}

Source: the author's computation on the basis of Eurostat (2014b) data

The analysis of the dynamics of labour productivity in the EU reveals the significant improvement in labour productivity if compared with the average productivity in the EU. It argues that economic crisis heavily influenced productivity and technologies applied that resulted in significant improvements and hence improved the competitiveness. The data show that during the fast economic growth period (2004-2007) the labour productivity in Latvia was $37-40 \%$ of the average level of the EU productivity, in Lithuania - 49-53\%, but in Estonia - 49-56\%. These countries have improved the labour productivity after the crisis, (Figure 2, white boxes). The crisis may have a dual impact on the economy - positive and negative. Hence, the crisis can also result in a decline of productivity and loss of competitiveness - as it is observed in Belgium, Italy, Luxembourg, the UK, Finland etc. (Figure 2, grey boxes) - the labour productivity is lower (resources are used in a less effective manner) in the post-crisis period (in 2013) than it was in 2000. 


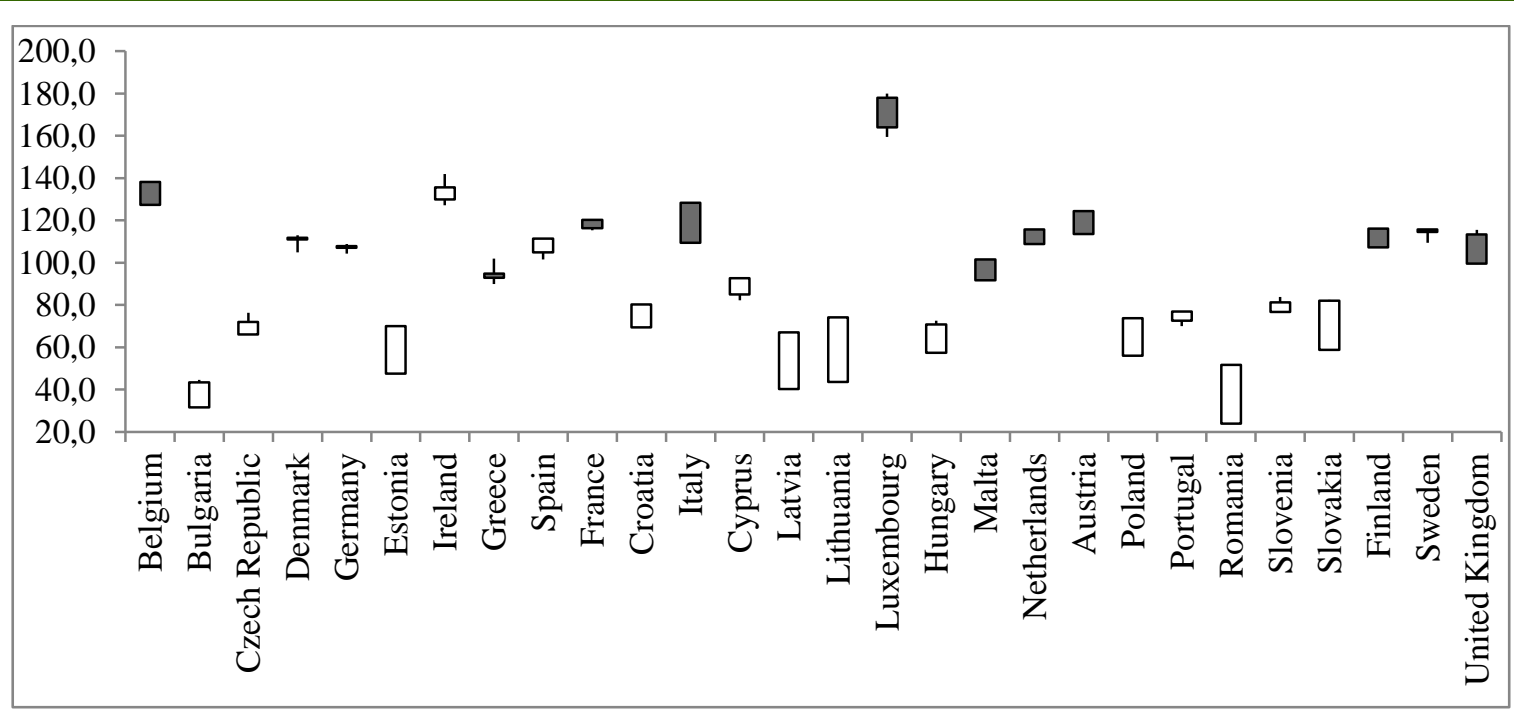

Figure 2. Dynamics of labour productivity in the EU (EU28=100) (2000-2013)

Source: the author's computation on the basis of Eurostat (2014b) data

The analysis of the relation between productivity per hour and real GDP growth rate in the three research periods argues that this relation between the indicators is unstable. The results argue that during the pre-crisis period the level of productivity had a small or no effect on the economic growth rate (Table 3), during the crisis productivity increased while the economies declined, but during the post-crisis period the productivity is higher than previously and it results in a stable economic growth with some time lag. Table 3 shows the annual dynamics of the indicators selected (labour productivity and real GDP growth rate) in three selected countries and the total performance of Euro Area in 2004-2012 (subdivided into three periods). There are observed almost no changes in the labour productivity of Euro Area countries (with respect to the EU average level) (it is in a stable position - 12-14\% above the average level of EU), and hence, most probably, the economic crisis was relatively light (as the economies are productive and efficient) and the recovery is weak and unstable (due to the impact of external factors as global demand decrease). At the same time, the cases of Estonia, Latvia, and Lithuania illustrate that the active steps, taken by the government and business during the crisis (as the EU funds, legislation, tax reliefs etc.), have resulted in a stable and notable recovery in respect to the average economic performance in the EU and Euro Area countries.

Table 3. Labour productivity and real GDP growth rate in the pre-crisis, crisis, and post-crisis period

\begin{tabular}{|c|c|c|c|c|c|c|c|c|c|}
\hline Indicators\Year & 2004 & 2005 & 2006 & 2007 & 2008 & 2009 & 2010 & 2011 & 2012 \\
\hline & \multicolumn{3}{|c|}{ Pre-crisis } & \multicolumn{3}{|c|}{ Crisis } & \multicolumn{3}{|c|}{ Post-crisis } \\
\hline \multicolumn{10}{|c|}{ Labour productivity per hour worked (Index $(E U 27=100))$} \\
\hline Latvia & 36.5 & 37.4 & 38.4 & 40.9 & 45.8 & 48.2 & 50.6 & 52.7 & 54.4 \\
\hline Estonia & 48.5 & 50.6 & 52 & 55.6 & 55.6 & 59.2 & 60.2 & 59.2 & 59.7 \\
\hline Lithuania & 49.9 & 49.2 & 51 & 52.9 & 54.1 & 51.2 & 59.1 & 63.2 & 63.8 \\
\hline Euro area (changing composition) & 114.0 & 114.3 & 114.4 & 114.3 & 114.4 & 113.9 & 113.3 & 113 & 112.8 \\
\hline \multicolumn{10}{|l|}{ Real GDP growth rate (\%) } \\
\hline Latvia & 8.8 & 10.1 & 11 & 10 & -2.8 & -17.7 & -1.3 & 5.3 & 5.2 \\
\hline Estonia & 6.3 & 8.9 & 10.1 & 7.5 & -4.2 & -14.1 & 2.6 & 9.6 & 3.9 \\
\hline Lithuania & 7.4 & 7.8 & 7.8 & 9.8 & 2.9 & -14.8 & 1.6 & 6.0 & 3.7 \\
\hline Euro area (changing composition) & 2.2 & 1.7 & 3.2 & 2.9 & 0.4 & -4.4 & 2 & 1.6 & -0.7 \\
\hline
\end{tabular}

However, it is very important to state that if even a maximum longest available (2000-2013) time series of labour productivity by Eurostat (2014a) are analysed, the results show that none of the EU current member state that had below $100 \%$ has gained the level above the EU average level. 
It once again claims that there are not just two speed economies in the EU, but two types of competitiveness of economies - high and low. There are not so many countries that have "an average level" (close to 100\%) - only - Greece, Spain, Malta (in some years the level +/-5\% from the average level). The above-mentioned countries experience economic problems and cannot be stated as a role models for the rest. Hence, the higher the labour productivity level (both in general and in comparison with the rest), the better for the economy today and for the future economic development and competitiveness.

The research results claim that the economic recovery strongly depends on the productivity increase during the crisis and after a certain period of time (transition period) it results in an economic growth. If the level of productivity stagnates or declines during the crisis, it results in a longer and deeper crisis and slower recovery.

Countries strive to improve their global competitiveness. One of the most common ways to measure global competitiveness is using GCI and hence countries aim to gain a higher rank. According to the GCI methodology ranking, the higher the rank the better for the national economy (for domestic companies, foreign investors etc.). However, as the number of countries included in GCI reports gradually increases from year to year (from 122 countries in the report of 2006-2007 to 148 countries in the report of 2013-2014), it should be stressed that a simplified general analysis of a country's rank over time might give biased results. Hence, it is important to analyse not only a rank, but also take into account the total number of countries covered by the report. This might be called a relative global competitiveness; it should be underlined that it is a completely different approach compared to the relative competitiveness of Podobnik et al. (2012).

The general analysis of GCI of Latvia, Lithuania, and Estonia shows that the global competitiveness in the post-crisis period is lower than it was in the pre-crisis period. For example, Latvia holds the 52nd place in 2013 in comparison with the 44th in 2006; Lithuania - the48th and the 39th, and Estonia - the32nd and the 26th respectively. However, if we take into account the above-mentioned point, we can argue that Latvia, Lithuania, and Estonia have gained back their relative global competitiveness as additional 26 countries are included in the ranking. In the postcrisis period, Estonia is again amid the top fifth of the countries with the highest global competitiveness, Lithuania and Latvia - amid the top third of the countries with the highest global competitiveness. Despite the fact that Latvia, Lithuania and Estonia had significantly lost their global competitiveness due to the severe economic recession, the countries have recovered and the trends show that the national competitiveness grows. The findings indicate that one of the main factors that ensure constant and stable improvement in the post-crisis period is the increase of labour productivity that results in stable economic growth.

\section{Discussion}

The goal of the research was to analyse the recent trends of labour productivity and economic growth in the post-crisis period in comparison with the trends in the pre-crisis and crisis periods in Latvia, Lithuania and Estonia. The results argue that the relation between the labour productivity and economic growth significantly differs and it is not a constant or stable relation over time. The findings argue that there are weak or no relations between the labour productivity and economic growth in the pre-crisis period and the first phase of post-crisis period. However, the increase of the labour productivity during the crisis is a significant driver of the economy after a period of time. The results of global competitiveness index analysis suggest that due to the labour productivity growth and the positive impact of other factors the countries have gained back the global competitiveness that was lost during the crisis.

The research findings can serve as an additional valuable resource for policy makers (in Latvia, Lithuania, and Estonia, as well in the EU countries that still are in crisis or just stepped into the post-crisis period) in order to make effective policy decisions and take actions on the basis of the relations between the labour productivity and economic growth, as well as taking into account the impact of labour productivity increase in the long-term, especially taking into account the time lag effect. 


\section{References}

Ahrend, R. (2006). Russian industrial restructuring: Trends in productivity, competitiveness and comparative advantage. Post-Communist Economies, 18(3), 277-295. doi: 10.1080/14631370600881770

Darvas, Z. (2011). Exchange rate policy and economic growth after the financial crisis in Central and Eastern Europe. Eurasian Geography and Economics, 52(3), 390-408. doi: 10.2747/1539-7216.52.3.390

Degutis, M. \& Tvaronavičiene, M. (2006). Factor analysis of Lithuanian and Estonian inward foreign direct investment. Business: Theory and Practice, 7(3), 150-157

Eurostat. (2014a). Auxiliary indicators to National Accounts - annual data. [Data file]. Retrieved from search http://epp.eurostat.ec.europa.eu/portal/page/portal/statistics/search_database

Eurostat (2014b). GDP and main components. [Data file]. Retrieved from search http://epp.eurostat.ec.europa.eu/portal/page/portal/statistics/search_database

Fagerberg, J. \& Srholec, M. (2007). The Competitiveness of Nations: Why Some Countries Prosper While Others Fall Behind. World Development, 35(10), 1595-1620. doi: 10.1016/j.worlddev.2007.01.004

Lall, S. (2001). Competitiveness Indices and Developing Countries: An Economic Evaluation of the Global Competitiveness Report. World Development, 29(9), 1501-1525. doi: 10.1016/s0305-750x(01)00051-1

Masso, J. \& Vahter, P. (2012). The link between innovation and productivity in Estonia's services sector. Service Industries Journal, 32(16), 2527-2541. doi: 10.1080/02642069.2011.600444

Podobnik, B., Horvatic, D., Kenett, D. Y. \& Stanley, H. E. (2012). The competitiveness versus the wealth of a country. Scientific Reports, 8. doi: 10.1038/srep00678

Rhee, K. \& Pyo, H. (2010). Financial crisis and relative productivity dynamics in Korea: Evidence from firm-level data (1992-2003). Journal of Productivity Analysis, 34(2), 111-131. doi: 10.1007/s11123010-0177-z

Sabonienè, A., Karazijienè, Ž (2012). Productivity dynamics in Lithuanian manufacturing industry. Economics and Management, 17(2), 560-566. doi: 10.5755/j01.em.17.2.2182

Snieska, V. \& Simkunaite, I. (2009). Socio-economic impact of infrastructure investments. Inzinerine Ekonomika-Engineering Economics, 3(63), 16-25

Xia, R., Liang, T., Zhang, Y. \& Wu, S. (2012). Is global competitive index a good standard to measure economic growth? A suggestion for improvement. International Journal of Services and Standards, 8(1), 45-57. doi: 10.1504/ijss.2012.048438

World Economic Forum. (2013). Global competitiveness report 2013-2014. Geneva, Switzerland: Author. Retrieved from http://www3.weforum.org/docs/WEF_GlobalCompetitivenessReport_2013-14.pdf

World Economic Forum. (2014). Global competitiveness index 2006-2007 to 2013-2014 [statistics]. Available from The Global Competitiveness Index data platform. Retrieved from http://www.weforum.org/issues/competitiveness-0/gci2012-data-platform/ 